\title{
Study of Sterilization and Disinfection in Room Air by Using Atmospheric Microplasma
}

\author{
Kazuo Shimizu*, Yuki Komuro, Shigeki Tatematsu and Marius Blajan \\ Innovation and Joint Research Center, Shizuoka University, Japan
}

\begin{abstract}
An effective and economical sterilization method is required due to the increase of the health consciousness in living spaces in the recent years, especially in the hospital, the airborne bacteria, and the surface colonized bacteria are the serious problem known as the hospital-acquired infection. Non-thermal plasma sterilization received a lot of attention as a replacement of traditional sterilization methods. Microplasma, which is atmospheric pressure nonthermal plasma, has been studied for application in various fields. It is a dielectric barrier discharge and has many advantages over other types of non-thermal plasmas, and is generated at atmospheric pressure thus does not require costly vacuum enclosures; the discharge voltage is about $600 \mathrm{~V}$ to $1.5 \mathrm{kV}$ and discharge gap is only 10 to $100 \mu \mathrm{m}$. Microplasma is suitable for applications not only indoor air cleaning, odor control, but also surface treatment or medical field because of the above mentioned advantages.
\end{abstract}

We investigated the remote sterilization effect and sterilization process for airborne bacteria by using atmospheric microplasma. Gram-negative bacteria Escherichia coli and Gram-positive bacteria Alicyclobatillus were the target to be sterilized in this study.

The experiment was performed with air and $\mathrm{Ar}$ as the process gases, to confirm the influence of different radical species in the microplasma, on the bacteria cultures. The process gas flows through the parallel plate electrodes with holes which were covered with dielectric material, and energized at about $600 \mathrm{~V} \sim 1.5 \mathrm{kV}$. Sterilization and disinfection was by microplasma carried out for both Gram-negative bacteria and Gram-positive bacteria, and resulted successfully.

Keywords: Atmospheric microplasma; Sterilization; Disinfection; Airborne bacteria; Surface colonized bacteria

\section{Background of Nonthermal Plasma for Sterilization and Disinfection}

Infective diseases such as new influenza strains caused by pathogenic organisms have been spread worldwide [1,2]. Recently this causes serious problems in schools and a lack of vaccines in many countries [3,4].

An effective and economical sterilization method is required due to the increase of the health consciousness in living spaces in the recent years, especially in the hospital. The airborne bacteria, and the surface colonized bacteria are the serious problem known as the hospitalacquired infection.

Nonthermal plasma sterilization received a lot of attention as a replacement of traditional sterilization methods. Active species are easily generated by non-thermal plasma and therefore used as a sterilization or inactivation tool for bacteria or bacteriophage [5-11]. It is expected to be alternatives to the other simple plasma techniques to purify indoor air.

These nonthermal plasma techniques were carried out with rather "high voltage" region ( $5-15 \mathrm{kV}$, sometimes more than $20 \mathrm{kV})$. In this article, a technique for indoor air control by microplasma will be introduced. We investigated the sterilization or disinfection and its sterilization process for the airborne bacteria, and the surface colonized bacteria by using atmospheric microplasma [12-17].

Microplasma, which is atmospheric pressure nonthermal plasma, has been studied for application in various fields. It is a dielectric barrier discharge and has many advantages over other types of non-thermal plasmas, and is generated at atmospheric pressure thus does not require costly vacuum enclosures; the discharge voltage is about $600 \mathrm{~V}$ to $1.5 \mathrm{kV}$ and discharge gap is only 10 to $100 \mu \mathrm{m}$, therefore a small and inexpensive power supply is necessary for obtaining a high intensity electric filed. Operation frequency depends on the power supply; few $\mathrm{kHz}$ to tens of $\mathrm{kHz}$ would be suitable for power supply without any heat problem. Microplasma could apply for various applications not only indoor air cleaning, odor control, but also surface treatment or medical field because of the above mentioned advantages [18-21].

\section{About Microplsama}

Our atmospheric microplasma is a type of dielectric barrier discharge (DBD) [22-24]. There are various types of microplasma. A classification could be established considering the generation method [25]: DC and hollow cathode discharge [26], dielectric barrier discharge [27], coronas [28], RF capacitively coupled [29], RF inductively coupled [30] and microwave microplasma [31]. The discharge gap is set to an order of micrometers which is extremely narrow, enabling the plasma to generate at a discharge voltage of around $600 \mathrm{~V}$. Streamers between the electrodes have also small diameters (in the order of micrometers), resulting in a relatively compact and dense plasma.

*Corresponding author: Prof. Kazuo Shimizu, Innovation and Joint Research Center, Shizuoka University, Japan, E-mail: shimizu@cjr.shizuoka.ac.jp

Received September 02, 2011; Accepted September 22, 2011; Published September 24, 2011

Citation: Shimizu K, Komuro Y, Tatematsu S, Blajan M (2011) Study of Sterilization and Disinfection in Room Air by Using Atmospheric Microplasma. Pharm Anal Acta S1:001. doi:10.4172/2153-2435.S1-001

Copyright: @ 2011 Shimizu K, et al. This is an open-access article distributed unde the terms of the Creative Commons Attribution License, which permits unrestricted use, distribution, and reproduction in any medium, provided the original author and source are credited. 
Figure $1(\mathrm{a})$ is an image of the microplasma during discharge. Streamers were generated not only between the electrodes but also around the holes of the electrodes. Figure 1(b) and 1(c) shows the streamers generated between the electrode which gap was set at $30 \mu \mathrm{m}$ and $100 \mu \mathrm{m}$. The diameter of generated streamers were $1 / 10$ to $1 / 100$ of wide gap (1 to $10 \mathrm{~mm}$ ) dielectric barrier discharge [32].

\section{Experimental Setup}

\section{Microplasma electrode and the reactor}

Discharge gap was set based on Paschens law, which indicates the minimum sparking voltage and discharge gap for various gases at atmospheric pressure. High reduced electric fields were readily obtainable with such small discharge gaps, resulting in a reduction of low energy electrons (1-2 eV), which dissociate ozone [33,34]. This microplasma electrode has the advantage of generating a high concentration of ozone with low discharge voltage and power.

Figure 2 shows the schematic image of microplasma electrodes for sterilization and disinfection of surface colonized bacteria. The electrodes were faced together with a spacer (thickness $100 \mu \mathrm{m}$, aperture area $\left.100 \mathrm{~mm}^{2}\right)$ in between. Due to small discharge gaps $(0 \sim 100) \mu \mathrm{m}$ and to the assumed specific dielectric constant of $10^{4}$, a high intensity electric field $\left(10^{7} \sim 10^{8} \mathrm{~V} / \mathrm{m}\right)$ could be obtained with relatively low discharge voltages around $1 \mathrm{kV}$. Streamers were generated between the electrodes as shown in Figure 1(b) and 1(c), which generate various radicals and ions that could affect a target surface $[18,19,21]$.

Figure 3 shows the experimental setup for sterilization or

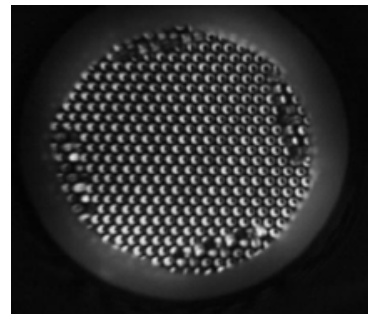

(a). $\mathrm{Vd}=1 \mathrm{kV}$, shutter opening $5 \mathrm{sec}$.

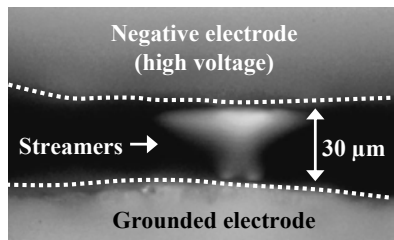

(b). $\mathrm{Vd}=1 \mathrm{kV}$, shutter opening $30 \mathrm{sec}$., gap distance was set at $30 \mu \mathrm{m}$, and streamer diameter was about $10 \mu \mathrm{m}$, Gas composition was $1 \% \mathrm{~N}_{2}$, and $99 \% \mathrm{Ar}$.

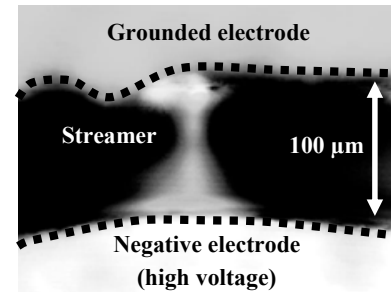

(c). $\mathrm{Vd}=1.4 \mathrm{kV}$, shutter opening 30 sec., gap distance was set at $100 \mu \mathrm{m}$, and streamer diameter was about $20 \mu \mathrm{m}$, Gas composition was $1 \% \mathrm{~N}_{2}$, and $99 \% \mathrm{Ar}$.

Figure 1: Image of the microplasma electrode (a: front view, b and c: side view)

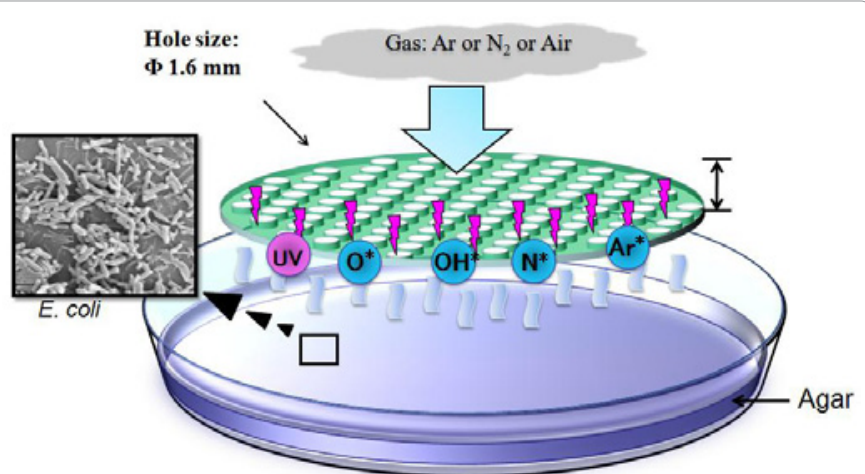

Figure 2: Schematic image of microplasma electrodes for sterilization and disinfection of surface colonized bacteria.

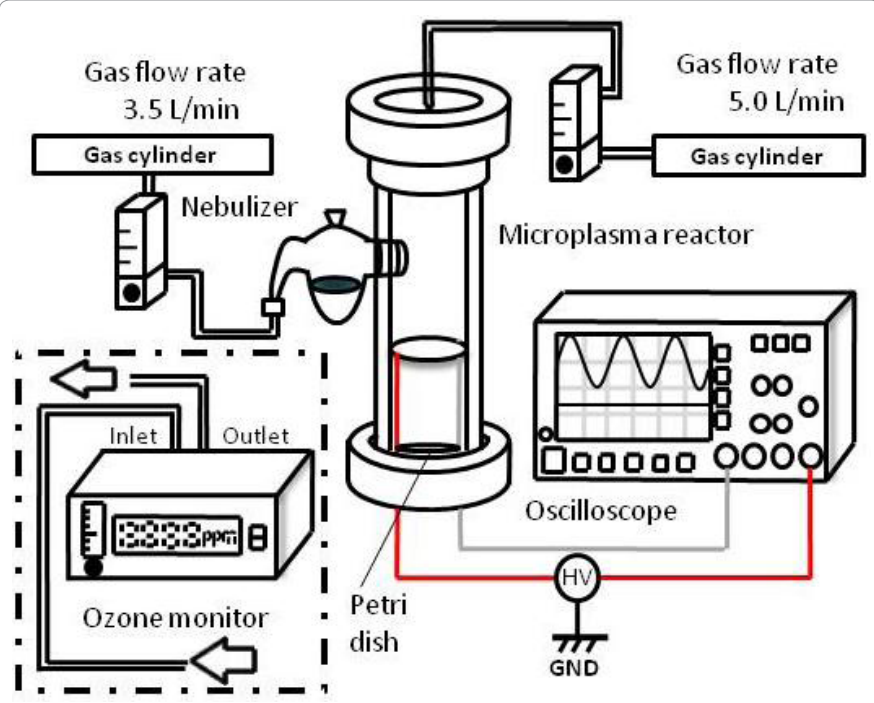

Figure 3: An experimental setup for sterilization and disinfection of airborne bacteria.

disinfection of the airborne bacteria. Escherichia coli JCM20135 and Bacillus subtilis JCB20036 were employed as the target to be sterilized. Preserved colonies of both E.coli JCM20135 and B. subtilis JCB20036 both maintained on agar at $2^{\circ} \mathrm{C}$ were diluted in liquid medium (Peptone from casein $5.0 \mathrm{~g} / \mathrm{L}$, Yeast extract $2.5 \mathrm{~g} / \mathrm{L}$, Glucose $1.0 \mathrm{~g} / \mathrm{L}$ ), ( 1 colony in $5 \mathrm{~mL}$ ). The liquid culture medium was introduced in the microplasma reactor and sprayed at a gas flow rate of $3.5 \mathrm{~L} / \mathrm{min}$ by use of a medical nebulizer, through the electrode against a Petri dish with culture medium. Air or nitrogen was also introduced as carrier gas to the reactor at a gas flow rate of $5 \mathrm{~L} / \mathrm{min}$. After microplasma treatment, Petri dishes were incubated 15 hours in the incubator at 37 degrees Celsius for E.coli JCM20135, and 18 hours at $30^{\circ} \mathrm{C}$ for $B$. subtilis JCB20036. Sterilization effect of microplasma was inspected by comparing the number of colonies with and without microplasma treatment.

The sterilization and disinfection experimental setup for surface colonized bacteria is shown in Figure 4. Escherichia coli JM109 and Alicyclobacillus were employed as the target to be sterilized.

Preserved colonies of E.coli JM109 maintained on agar at $2{ }^{\circ} \mathrm{C}$ were diluted in liquid medium (Peptone from casein $5.0 \mathrm{~g} / \mathrm{L}$, Yeast extract 
$2.5 \mathrm{~g} / \mathrm{L}$, Glucose $1.0 \mathrm{~g} / \mathrm{L})$ with $5 \mu \mathrm{l}$ of ampicillin $(\times 1,000$ stock $),(1$ colony in $5 \mathrm{~mL}$ ). The $40 \mu \mathrm{l}$ of suspension was applied to agar medium (MERCK, Casein-peptone glucose yeast exact agar) with ampicillin $1 \mu \mathrm{l} / 1 \mathrm{ml})$. Ampicillin was added for preventing contamination. Preserved colonies of Alicyclobacillus maintained on agar at $2^{\circ} \mathrm{C}$ were diluted in liquid medium (NBRC, Growth medium No. 323) (1 colony in $5 \mathrm{~mL}$ ). The $40 \mu \mathrm{l}$ of suspension was applied to agar medium (NBRC, Growth medium No. 323).

The experiments were performed with Ar and Air as the process gases. Process gases were flowed into the reactor from the top and flown through the holes of electrodes. The electrodes were attached to a glass pipe and inserted in to an acrylic pipe in order to keep a controlled gas composition around the electrodes and target to be sterilized. A Petri dish was set on the stage under the electrodes and exposed to remote microplasma.

After microplasma treatment, Petri dishes were incubated 16 hours in the incubator at $37^{\circ} \mathrm{C}$ for E.coli JM109, and 18 hours at $45^{\circ} \mathrm{C}$ for Alicyclobacillus.

\section{Power supply}

A neon transformer was used as an AC high voltage power supply for the sterilization processes (LECIP, M-1H shown in Figure 5(a)). Applied voltage to electrodes was adjusted by variable transformer (RIKO-ALIDETRANS). Frequency of AC voltage was about $25 \mathrm{kHz}$ and maximum output was about $1.4 \mathrm{kV}$.

Pulse power supply was used to carry out the emission spectroscopy to analyze the opto-physical characteristics of microplasma as shown in Figure 6. This self made pulse power supply with MOSFET switches energized the electrodes and controlled the plasma emission and an ICCD camera by trigger signal $[19,35]$. It generates negative pulses up to $-1.6 \mathrm{kV}$, rise time $80 \mathrm{~ns}$ and pulse width varied from $100 \mathrm{~ns}$ to $5 \mu \mathrm{s}$.

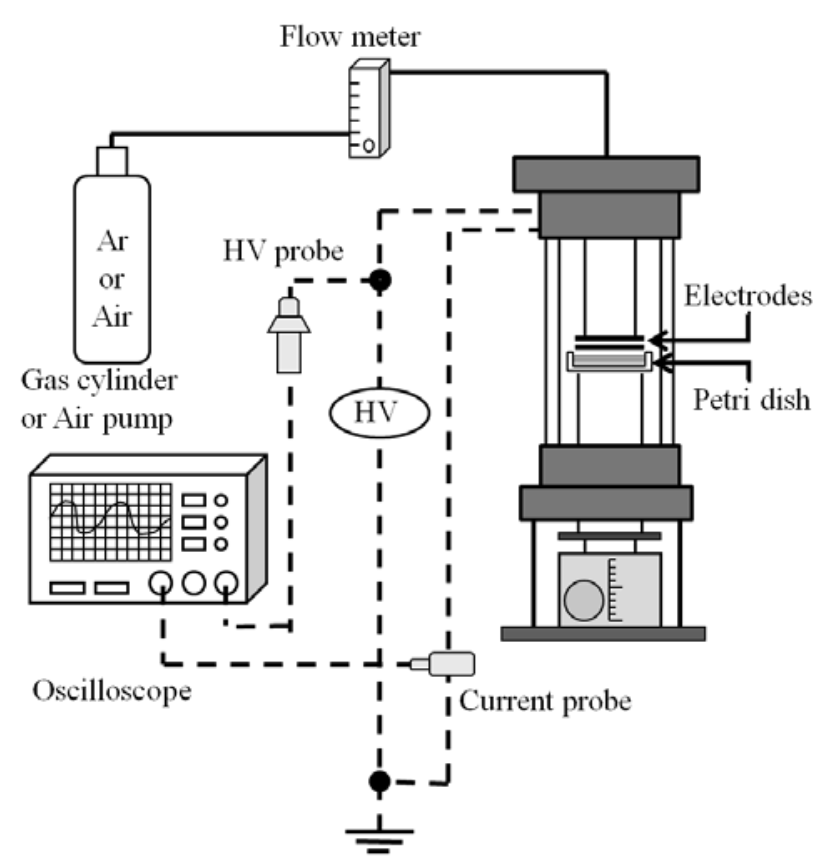

Figure 4: An experimental setup for sterilization and disinfection of surface colonized bacteria.

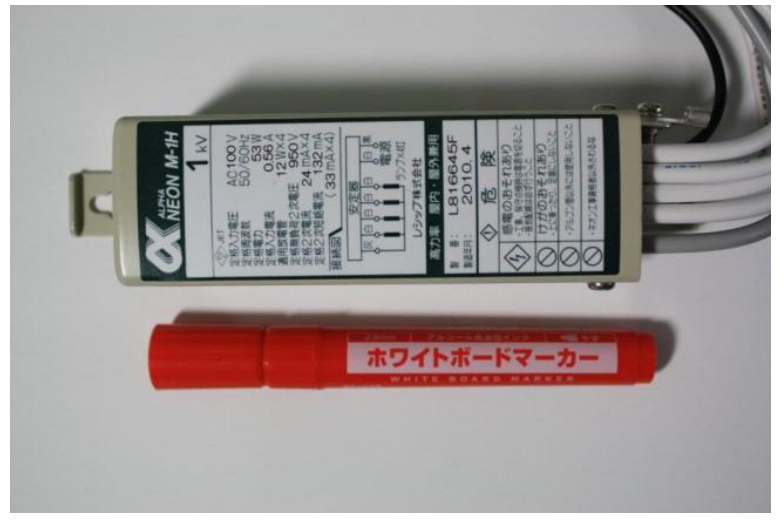

(a) Image of an AC power supply

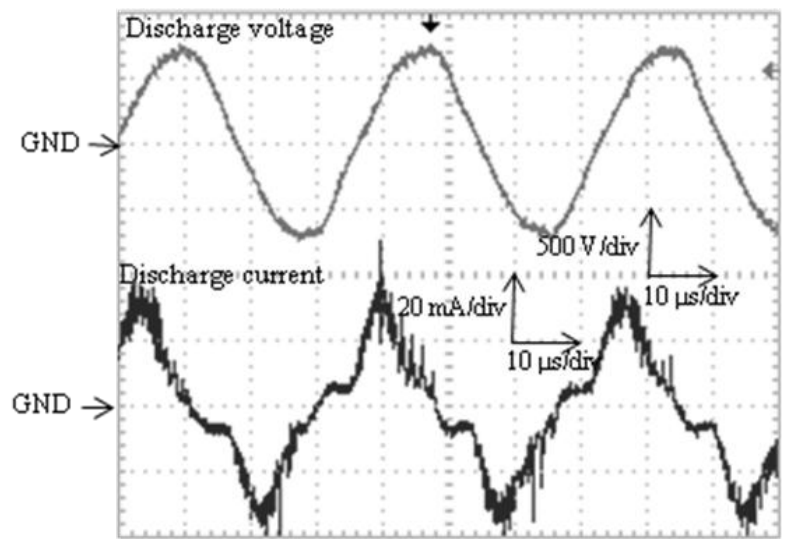

(b) Process gas Ar

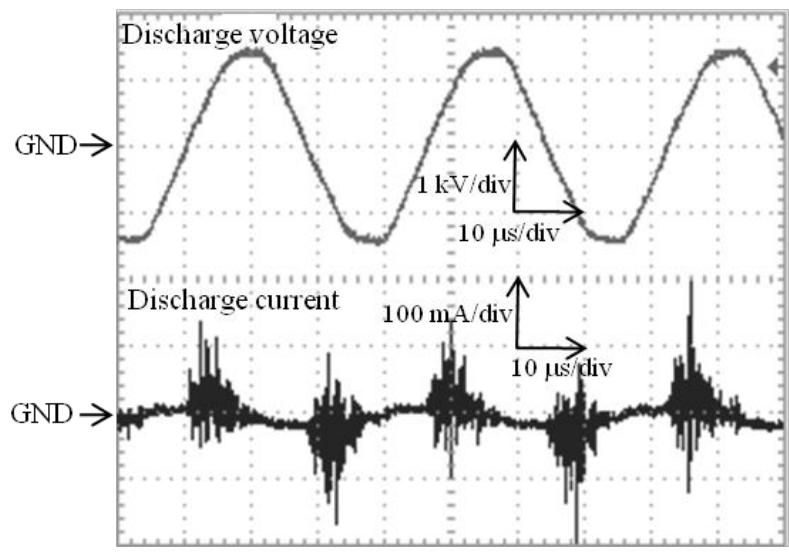

(c) Process gas air

Figure 5: Image of a small AC power supply (a), typical waveform of microplasma with $\mathrm{AC}$ neon transformer for both $\mathrm{Ar}$ (b) and air microplasma (c).

The electronic circuit for generating pulse voltage is shown in Figure 6(a).

\section{Results and Discussion}

Discharge waveform and power for generating microplasma

Figures 5(b) and 5(c) shows the typical waveform of discharge voltage and corresponding discharge current generating microplasma 
at about $1 \mathrm{kV}$. This waveform shows alternate current and frequency is about $25 \mathrm{kHz}$. Corresponding discharge current showed a typical waveform of dielectric barrier discharge. The microplasma reactor can generate atmospheric plasma at about $1 \mathrm{kV}$, since its discharge gap was narrow (about 10 to $100 \mu \mathrm{m}$ ) [12-17].

The typical waveforms of pulse voltage by a self-made circuit are shown in Figure 6(b) and 6(c) Rise time of discharge voltage by a pulse power circuit was $80 \mathrm{~ns}$, and pulse width was varied from $100 \mathrm{~ns}$ to $4 \mu \mathrm{s}$. Sharp discharge current was observed at a rising part of the a negative pulse.

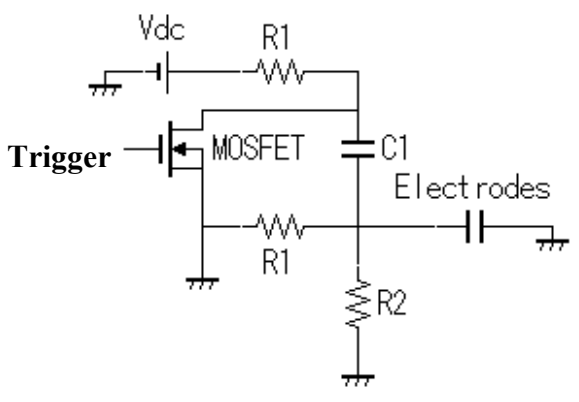

(a)

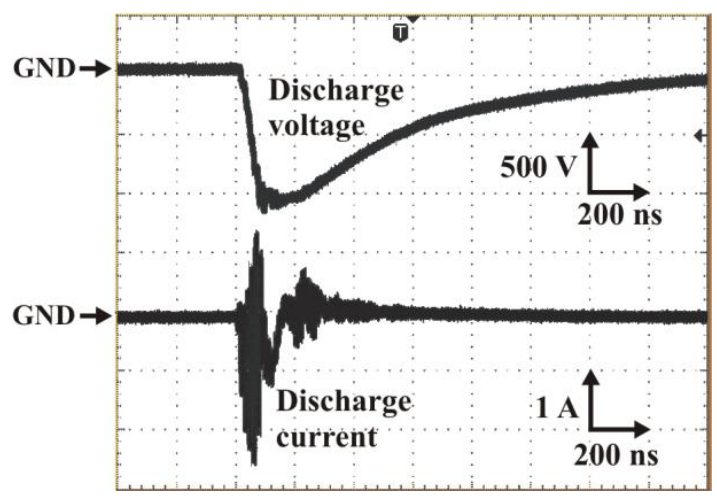

(b) Width of pulse voltage: $200 \mathrm{ns,}$

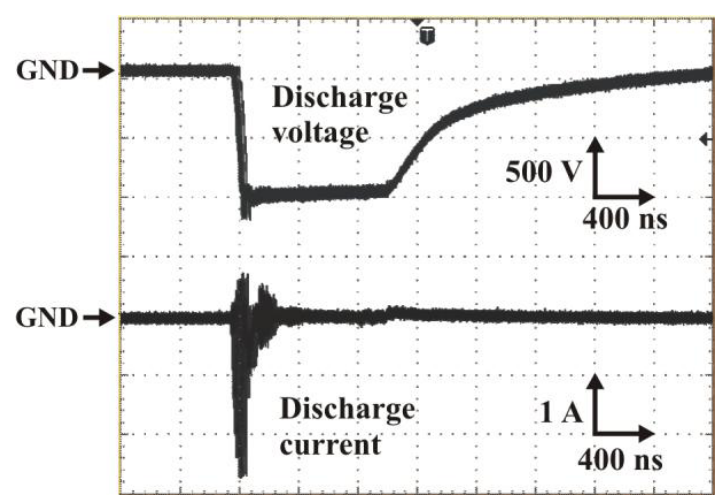

(c) Width of pulse voltage: $1 \mu \mathrm{s}$.

Figure 6: An example of a pulse circuit with the MOSFET switch (a); discharge voltage and corresponding discharge current by a pulse power circuit (b) and (c).

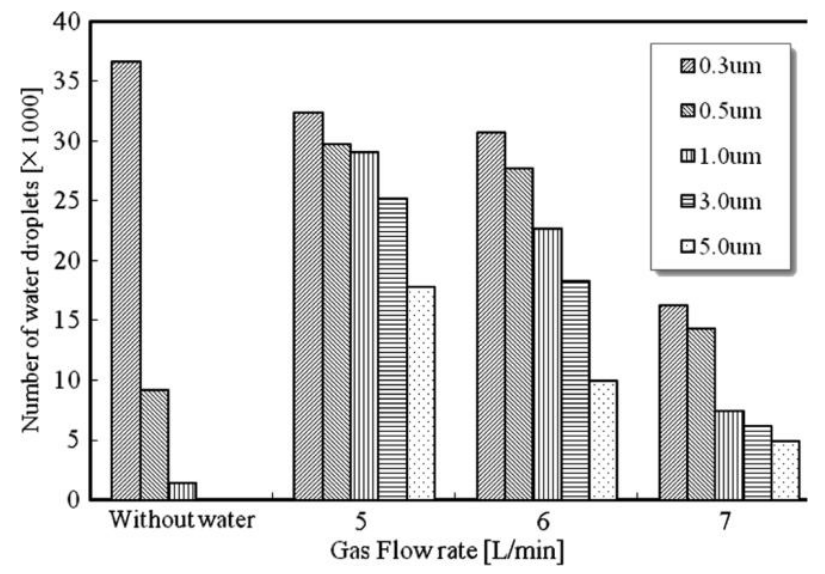

Figure 7: Size distribution of water particles generated in by the nebulizer at gas flow rates of 5,6 , and $7 \mathrm{~L} / \mathrm{min}$.

Thought the waveforms are different from Figures 5 and 6, microplasma generation was confirmed with all the applied voltage, since the microplasma was generated by typical dielectric barrier discharge. The indoor air control devices in the market are usually driven by weak corona discharge ranged from 5 to $10 \mathrm{kV}$ without dielectric barriers on their electrodes. This is a significant difference between the microplasma technique under discussion here, and the technique employed by indoor air control devices on the market now which generate ions to disinfect the bacteria, according to the manufacturers claims [36].

\section{Sterilization of airborne bacteria by microplasma}

Virus or bacteria contained in tiny water droplets suspended in room air known as airborne bacteria could cause serious illnesses such as influenza. One pass treatment of microplasma (shown in Figure 3) can be an effective sterilization method for indoor air.

The diameters of the water particles formed by a medical nebulizer were measured by a laser particle counter (Kanomax 3886). The gas flow rate was restricted to the range of 5-7 $\mathrm{L} / \mathrm{min}$ because the pressure loss of the nebulizer was high.

As shown in Figure 7, a particle counter observed particles with diameters of 0.3 and $0.5 \mu \mathrm{m}$ without water in the nebulizer. These particles could be the dust in the room air. With water added to the nebulizer, water droplets with diameters ranging from 0.5 to $5 \mu \mathrm{m}$ were generated at the applied gas flow rates of 5, 6, and $7 \mathrm{~L} / \mathrm{min}$. Smaller water droplets did not coalesce to form larger droplets because the number of $0.5 \mu \mathrm{m}$ droplets exceeds the number of $1.0 \mu \mathrm{m}$ droplets. Since the sizes of colon bacilli Escherichia coli JCM20135 and Bacillus subtilis JCB 20036 are about 0.5 to $2.5 \mu \mathrm{m}$, they were contained within the water droplets generated by the nebulizer.

Inactivation of Escherichia coli and Bacillus subtilis were experimentally investigated at a total gas flow rate of $8.5 \mathrm{~L} / \mathrm{min}$ by using microplasma electrodes. Ambient air and nitrogen were used to compare the effect of the oxidization effect of ozone and to confirm the effect of high electric field and UV radiation from microplasma.

Photographs of Petri dishes with E. coli, before and after the microplasma treatment with air and nitrogen as the carrier gases, are shown in Figure 8. Incubated condition was described in previous 

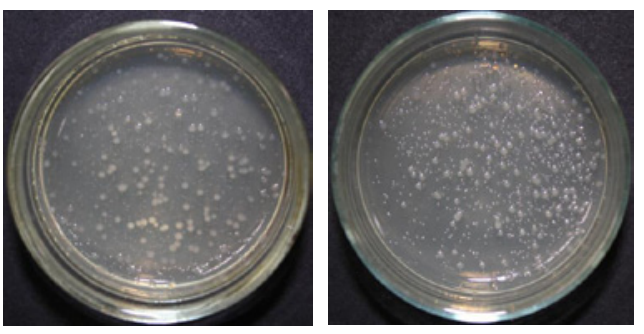

(a) Before treatment.

(b) Discharge voltage $1.0 \mathrm{kV}$

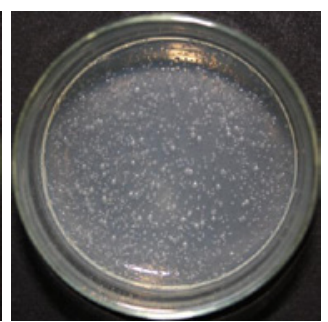

(e) Discharge voltage $1.0 \mathrm{kV}$.

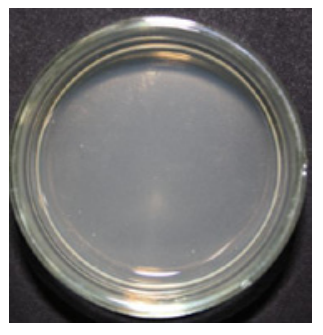

(c) Discharge voltage $1.4 \mathrm{kV}$.

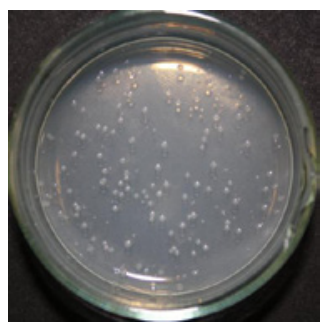

(f) Discharge voltage $1.4 \mathrm{kV}$.

Figure 8: Images of the airborne bacteria (E.coli JCM20135) colonies before and after the air plasma treatment ((a)-(c)) and that for the nitrogen plasma treatment $((d)-(f))$.
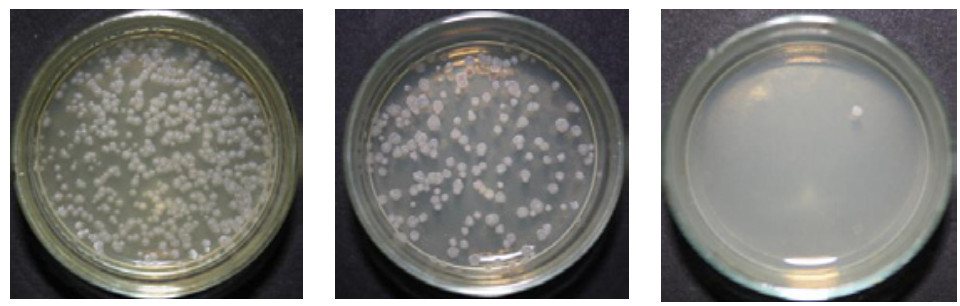

(a) Before treatment.

(b) Discharge voltage 1. $0 \mathrm{kV}$.

(c) Discharge voltage $1.4 \mathrm{kV}$.
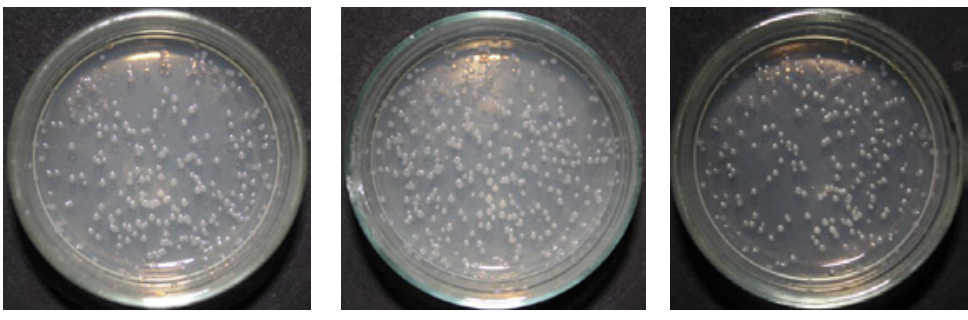

(d) Before treatment.

(e) Discharge voltage 1. 0 kV.

(f) Discharge voltage $1.4 \mathrm{kV}$

Figure 9: Images of the airborne bacteria (B. subtilis JCB20036) colonies before and after the air plasma treatment ((a)-(c)) and that for the nitrogen plasma treatment $((d)-(f))$.

section "3.1 Microplasma electrode and the reactor". Decrease of the colonies was observed both for air plasma and nitrogen plasma.

From these photos, air plasma had better results to sterilize E.coli than that with nitrogen plasma. In the case of nitrogen as carrier gas, the presence of oxidation species such as ozone was not confirmed. This could explain the difference between air and nitrogen.

Photographs of Petri dishes with B.subtilis, before and after the microplasma treatment with air and nitrogen as the carrier gases, are shown in Figure 9. Incubated condition was described in previous section "3.1 Microplasma electrode and the reactor". A decrease of the number of colonies was observed when the discharge voltage increased in both air plasma and nitrogen plasma. Decrease of the colonies was rather low compared to the of E.coli results. The inactivation process for bacteria may occur between the electrodes that generate microplasma 
or in the space near the electrodes after passing through the holes of the electrodes.

As evident in these photos, more effective results were obtained for E. coli (gram-negative bacteria) than that of B. subtilis spore. Lower sterilization of $B$. subtilis (gram-positive bacteria spore) could be caused by its relatively impermeable cell walls, which have a thickness in the range of 22 to $25 \mathrm{~nm}$. The cell wall of gram-positive bacteria is composed of peptidoglycan and secondary polymers. Gram-negative bacteria have thin peptidoglycan layers $(2-3 \mathrm{~nm})$ plus an overlying lipid-protein bilayer (7-8 $\mathrm{nm}$ ) known as the outer membrane [37,38].

Sterilization rate of E. coli versus discharge voltages by air plasma and nitrogen plasma is shown in Figure 10. 100\% sterilization of airborne bacteria (E. coli JCM20135) was accomplished with air as carrier gas by microplasma as shown in Figure 10. When nitrogen was the carrier gas, the sterilization rate surpassed $90 \%$ corresponding to a discharge voltage of $1.4 \mathrm{kV}$. Concentration of ozone was measured by an ozone monitor (Seki Electronics SOZ 3300). Ozone was not formed during the discharge in the presence of nitrogen, and the sterilization of E. coli could be considered to be due to the effects of high electric field, excited nitrogen ions, active species such as $\mathrm{OH}$, and $\mathrm{UV}$ radiation by microplasma, as described below in the next section.

Sterilization rate of B. subtilis versus discharge voltage by air plasma and nitrogen plasma is shown in Figure 11. When air was used as carrier gas, maximum concentration of ozone was $22 \mathrm{ppm}$ in the reactor. The effective reactor volume was $0.2 \mathrm{~L}$, and the gas residence time of the reactor was about 1.4 seconds. When air was used as carrier gas, a near $100 \%$ sterilization rate of $B$. subtilis was achieved at discharge voltage of $1.4 \mathrm{kV}$. With nitrogen as the carrier gas, a sterilization rate of about $30 \%$ was achieved for B. subtilis. From this result, the sterilization process could be considered a synergetic effect of UV radiation, high electric field, (not only oxidative) radicals, and ozone. Various investigators show the sterilization effect (not by microplasma but) by atmospheric plasma or plasma jet [39-43].

Sterilization or disinfection of the airborne bacteria was immediately done, when the airborne bacteria was passing through between the microplasma electrodes. Since treating time of the one pass process was fixed where less than $100 \mu \mathrm{s}$, the $\mathrm{D}$ value is calculated by changing the applied voltage, for both $E$. coli and B. subtilis. The fraction negative

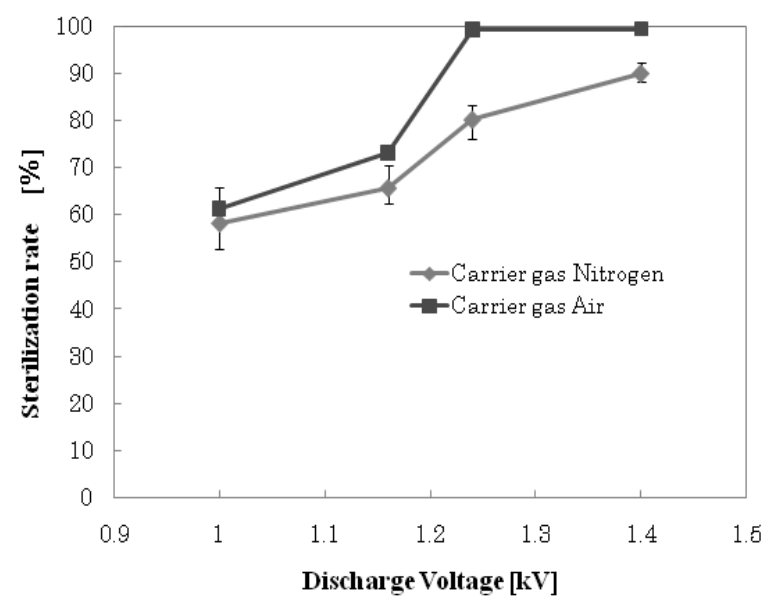

Figure 10: Comparison of sterilization rate of E.coli with air and nitrogen plasma

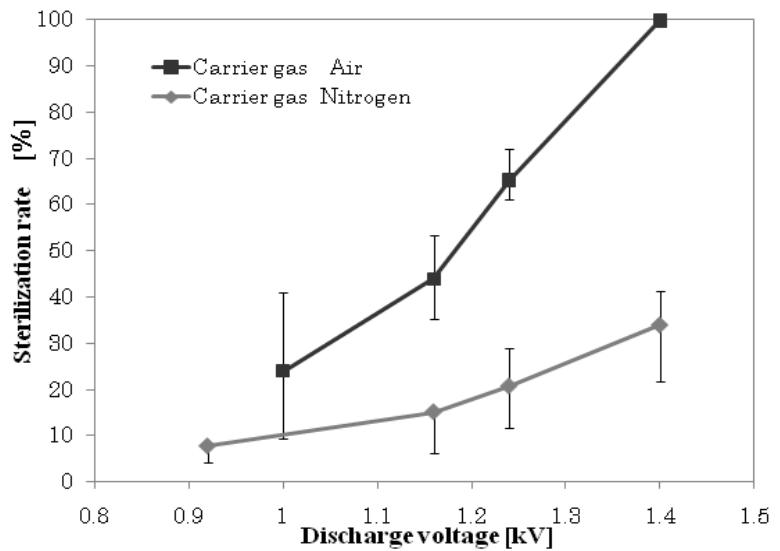

Figure 11: Comparison of sterilization rate of $B$. subtilis with air and nitrogen plasma.

\begin{tabular}{|l|l|l|l|l|}
\hline $\begin{array}{l}\text { Discharge } \\
\text { voltage }[\mathrm{kV}]\end{array}$ & $\begin{array}{l}\text { D value for } \\
\text { E. coli by } \\
\text { air plasma } \\
{[\mathrm{kV}]}\end{array}$ & $\begin{array}{l}\text { D value for } E . \\
\text { coli by nitrogen } \\
\text { plasma }[\mathrm{kV}]\end{array}$ & $\begin{array}{l}\text { D value for } B . \\
\text { subtilis by air } \\
\text { plasma }[\mathrm{kV}]\end{array}$ & $\begin{array}{l}\text { D value for } \\
\text { B. subtilis by } \\
\text { nitrogen plasma } \\
{[\mathrm{kV}]}\end{array}$ \\
\hline 1.00 & 0.270 & 0.289 & 0.452 & 0.505 \\
\hline 1.16 & 0.290 & 0.324 & 0.440 & 0.545 \\
\hline 1.24 & 0.247 & 0.322 & 0.427 & 0.569 \\
\hline 1.40 & 0.259 & 0.334 & 0.293 & 0.596 \\
\hline
\end{tabular}

Table 1: The $D$ value of $E$. Coli and $B$. subtilis for various discharge voltage of both air and nitrogen microplasma.

method of Stumbo Murphy Cochran Procedure (SMCP) was used for calculation of the D value according to the ISO14161 method [44]. The calculated D value is shown in Table 1 . The best valuse was $0.247 \mathrm{kV}$ obtained with air plasma at the discharge voltage of $1.24 \mathrm{kV}$ for the case of E. coli.

\section{Sterilization and disinfection of surface colonized bacteria}

To examine the impact of gas, only Ar gas without microplasma was flown towards the Petri dish. Figure 12 (a) and (b) shows the result of Ar gas exposure treatment. The E.coli culture was diluted by 104, and applied to the agar medium. Ar gas flow rate was $10 \mathrm{~L} / \mathrm{min}$ at the distance $2 \mathrm{~mm}$ between agar medium and electrodes. The exposure time was 60 seconds and the sample was cultured again. Incubated condition was described in previous section "3.1 Microplasma electrode and the reactor". No sterilization effect was observed by comparing the Petri dish before and after the treatment with only Ar gas as shown in Figure 12 (a) and (b).

Figure 12 (c) to (f) shows the experimental result of sterilization of E.coli by using atmospheric Ar microplasma. Discharge voltage was set between $650 \sim 850 \mathrm{~V}$. Ar gas flow rate was $10 \mathrm{~L} / \mathrm{min}$ and the agar medium was exposed at $2 \mathrm{~mm}$ distance from electrodes. Exposure time was 60 seconds. Sterilization effect was observed near the center of Petri dish and sterilization area expanded with the increase of applied voltage. Electrical damage to sample could not be considered because the electric field was closed between electrodes. Thus it is considered that the sterilization effect occurred due to the action of excited Ar and $\mathrm{OH}$ radical which could be also generated on the agar surface. The mechanisms of sterilization will be discussed in the next section.

Figure 13 shows the experimental result of sterilization of E.coli by using atmospheric Air microplasma. Discharge voltage was set 
Citation: Shimizu K, Komuro Y, Tatematsu S, Blajan M (2011) Study of Sterilization and Disinfection in Room Air by Using Atmospheric Microplasma. Pharm Anal Acta S1:001. doi:10.4172/2153-2435.S1-001

between $1.3 \sim 1.5 \mathrm{kV}$. Air gas flow rate was $10 \mathrm{~L} / \mathrm{min}$ and the agar medium was exposed at $2 \mathrm{~mm}$ distance from electrodes. Exposure time was 60 seconds. Microplasma discharge in air treatment sterilized a wider area than microplasma discharge in Ar. This could be due to the long lifetime active species derived from $\mathrm{O}_{2}$. However, Ar microplasma sterilization affected the center of Petri dish and the effect was stronger than air microplasma treatment.

The $\mathrm{D}$ value for treating the surface colonized bacteria (E. Coli JM109) was also calculated as shown in Table 2. The best case, where discharge voltage was $1.40 \mathrm{kV}$, exporsure time was 30 seconds, and in the room temperature, was $0.416 \mathrm{kV}$ obtained by the fraction negative method of Stumbo Murphy Cochran Procedure (SMCP) according to the ISO14161 method [36]

\section{Emission spectrum observation of microplasma}

UV light emissions from microplasma were observed to confirm the effect of UV light on the bacteria sterilization process [19,35]. The emission spectra were measured by an intensified charge-coupled device (ICCD) camera (Ryoushi-giken, SMCP-ICCD 1024 HAMNDS/UEmV), a spectrometer (Ryoushi-giken, VIS 351), and by a photomultiplier tube (Hamamatsu Photonics, R3896). A pulse

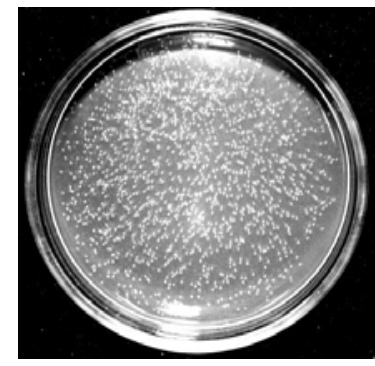

(a) Before treatment

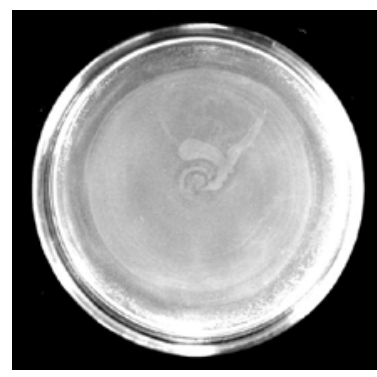

(c) No treatment

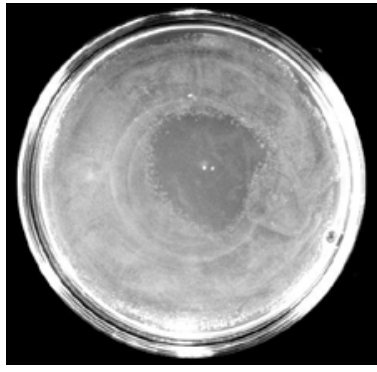

(e) Ar microplasma treatment $750 \mathrm{~V}$

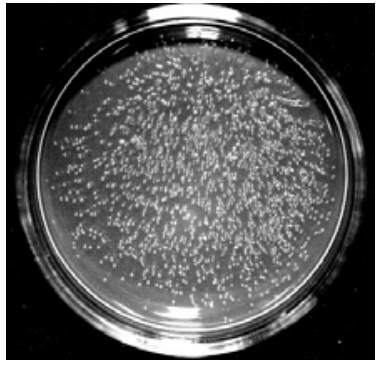

(b). After the Ar gas exposure treatment

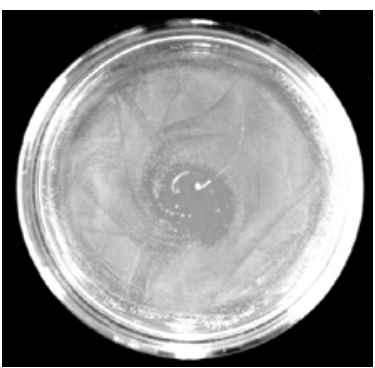

(d) Ar microplasma treatment $650 \mathrm{~V}$

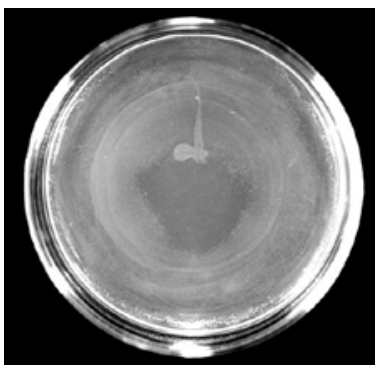

(f) Ar microplasma treatment $850 \mathrm{~V}$
Figure 12: Sterilization of the surface colonized bacteria by Ar microplasma.

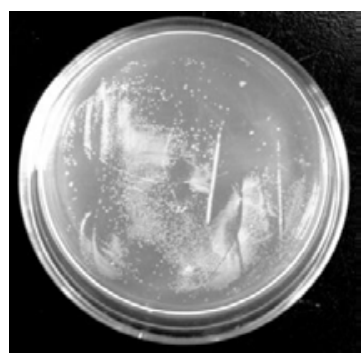

(a) No treatment

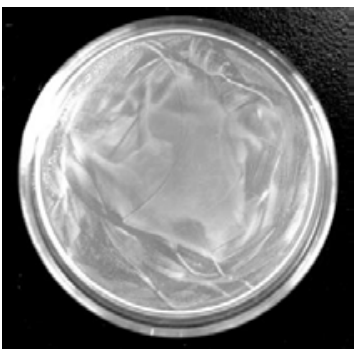

(c) Air microplasma treatment $1.4 \mathrm{kV}$
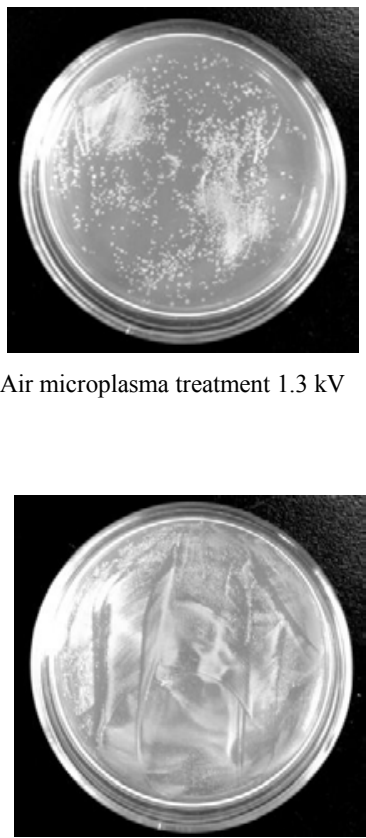

(d) Air microplasma treatment $1.5 \mathrm{kV}$ (b) Air microplasma treatment $1.3 \mathrm{kV}$

Figure 13: Sterilization of the surface colonized bacteria by Air microplasma.

\begin{tabular}{|l|l|l|l|l|}
\hline Discharge voltage [kV] & 1.30 & 1.40 & 1.50 & 1.60 \\
\hline D value $[\mathrm{kV}]$ & 0.461 & 0.416 & 0.441 & 0.450 \\
\hline
\end{tabular}

Table 2: The D value of $E$. Coli JM109 for various discharge voltage of microplasma (Exposure time;30 seconds, room temperature, process gas; air).

generator (Tektronix, AFG 3021B) was used to trigger the ICCD camera and the pulse power supply consisting of semiconductor switches. The spectrum was observed at $-1.4 \mathrm{kV}$ with a pulsewidth of $500 \mathrm{~ns}$ and a frequency of $1 \mathrm{kHz}$. The gas flow rate of dry nitrogen was set at $5 \mathrm{~L} / \mathrm{min}$. Data obtained from the ICCD camera were transferred to a computer for analysis.

Figure 14 (a) shows the emission spectrum of the microplasma discharge in $\mathrm{N}_{2}$. Higher peaks indicate the $\mathrm{N}_{2}$ second positive band system ( $\mathrm{N}_{2}$ SPS) and smaller peaks indicate the $\mathrm{N}_{2}$ first negative band system $\left(\mathrm{N}_{2}^{+}\right.$FNS). The spectrum indicates the generation of active molecular nitrogen species in the microplasma discharge [45].

The elementary processes (1) and (2) describe the radiation kinetics for the $\mathrm{N}_{2}$ SPS with a wavelength of $337.1 \mathrm{~nm}$ and at atmospheric pressure [46].

The excitation of nitrogen molecules in the ground state by direct electron impact is described by reaction (1).

$$
e+\mathrm{N}_{2}\left(X^{1} \Sigma_{g}{ }^{+}\right)_{v=0} \rightarrow \mathrm{N}_{2}\left(\mathrm{C}^{3} \pi_{u}\right)_{v^{\prime}=0}+e(\Delta E=11 \mathrm{eV})
$$

The spontaneous radiation of nitrogen in the excited state is described by reaction (2).

$$
\mathrm{N}_{2}\left(\mathrm{C}^{3} \pi_{u}\right)_{v^{\prime}=0} \rightarrow \mathrm{N}_{2}\left(\mathrm{~B}^{3} \pi_{g}\right)_{v^{\prime \prime}=0}+h v\left(\tau_{0}^{C}=40 \mathrm{~ns}\right)
$$

Water droplets from the nebulizer were entrained in the nitrogen gas that could generate the other active species in the microplasma discharge [14]. 
Citation: Shimizu K, Komuro Y, Tatematsu S, Blajan M (2011) Study of Sterilization and Disinfection in Room Air by Using Atmospheric Microplasma. Pharm Anal Acta S1:001. doi:10.4172/2153-2435.S1-001

Figure 14 (b) shows the intensity of excited Ar atoms generated by electron collision [47]. OH radical is generated by the reaction of excited $\mathrm{Ar}$ with $\mathrm{H}_{2} \mathrm{O}$ derived from the walls inside the box. The peaks corresponding to $\mathrm{OH}$ radical were measured at $306.4,307.8$ and 308.9 $\mathrm{nm}$ for the microplasma discharge in Ar as shown in Figure 14(c). Also it is considered that $\mathrm{OH}$ radical was generated by the reaction of excited $\mathrm{Ar}$ with $\mathrm{H}_{2} \mathrm{O}$ derived from the moisture of agar medium as reaction (3) [48].

$$
\operatorname{Ar}^{\star}(4 \mathrm{p})+\mathrm{H}_{2} \mathrm{O} \rightarrow \operatorname{Ar}(3 \mathrm{p})+\mathrm{OH}\left(\mathrm{A}^{2} \Sigma^{+}\right)+\mathrm{H}
$$

$\mathrm{OH}$ radical can contribute to the higher sterilization efficiency $[49,50]$. The UV light emission confirmed active species such as $\mathrm{OH}$ radicals measured at $306.4 \mathrm{~nm}, 307.8 \mathrm{~nm}$ and $308.9 \mathrm{~nm}[45,51]$. UV light emissions from $316 \mathrm{~nm}$ and higher wavelengths were also observed, which affect the sterilization process of bacteria $[52,53]$.

$\mathrm{OH}$ radicals are generated via electron impact dissociation of $\mathrm{H}_{2} \mathrm{O}$
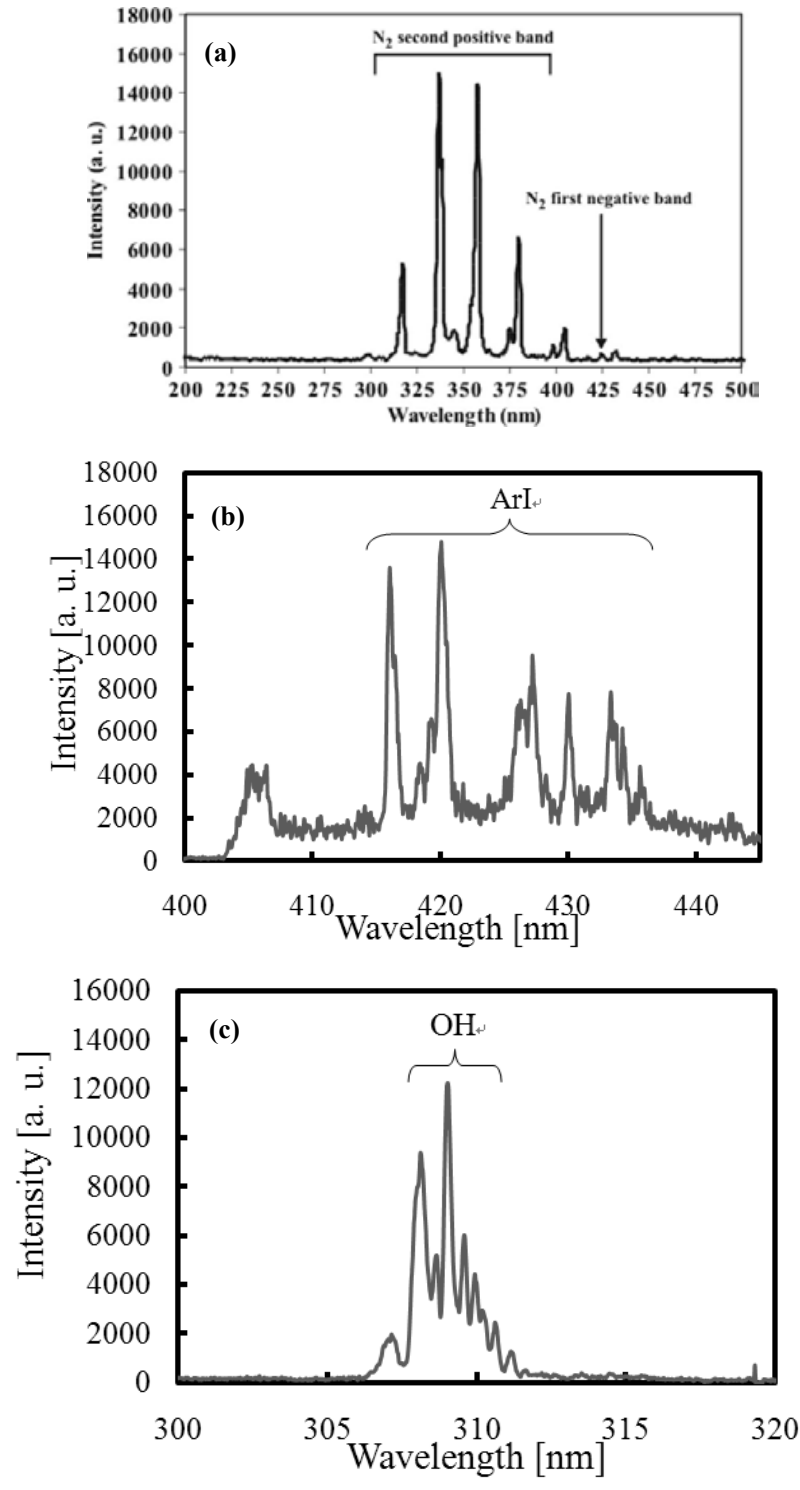

Figure 14: Emission spectrum of microplasma: $\mathrm{N}_{2}$ second positive band system and $\mathrm{N}_{2}$ first negative band system from discharge in nitrogen (a) excited $\mathrm{Ar}$ atoms (b) and excited $\mathrm{OH}$ radical.

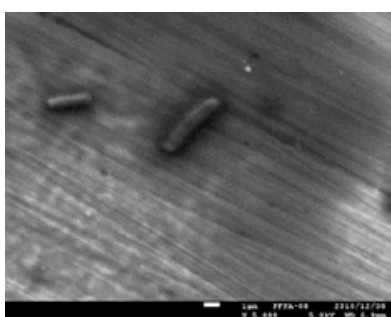

(a) before treatment ( $\mathrm{x} 5000)$

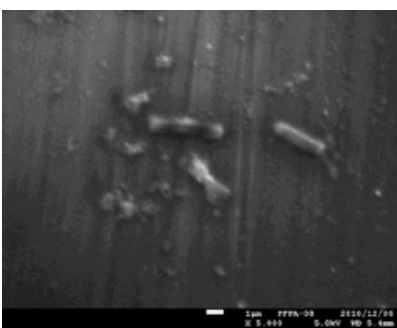

(c) after treatment $(\mathrm{Vd}=1.0 \mathrm{kV}, \mathrm{x} 5000)$

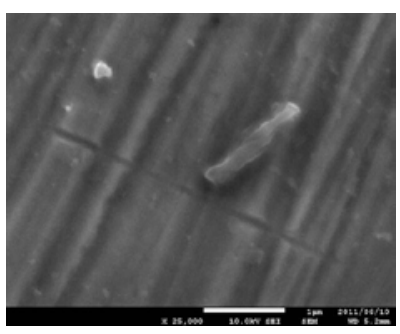

(e) after treatment $(\mathrm{Vd}=1.2 \mathrm{kV}, \mathrm{x} 25000)$

Figure 15: Photographs of B.subtilis before and after the microplasma treatment taken by SEM.

which leads to the production of $\mathrm{H}$ and $\mathrm{OH}$ radicals shown reactions (4) and (5) [54,55].

$$
\mathrm{e}+\mathrm{H}_{2} \mathrm{O} \rightarrow \mathrm{e}+\mathrm{H}^{*}+\mathrm{OH}^{*}
$$

Also, the excited state $\mathrm{O}\left({ }^{1} \mathrm{D}\right)$ dissociated $\mathrm{H}_{2} \mathrm{O}$ to generate $\mathrm{OH}^{*}$ :

$$
\mathrm{O}\left({ }^{1} \mathrm{D}\right)+\mathrm{H}_{2} \mathrm{O} \rightarrow 2 \mathrm{OH}^{*}
$$

Thus $\mathrm{OH}$ radical peak was obtained in the presence of $\mathrm{H}_{2} \mathrm{O}$ in air or in nitrogen. The combination of UV light emitted from 250 to $300 \mathrm{~nm}$ known as NO- $\gamma$ band, and active species could have contributed to the sterilization process of bacteria in suspended air [35].

\section{Bacteria morphology observation by SEM}

Figure 15 shows the photograhps of B. subtilis before and after sterilization by microplasma. The images were taken by a Field Emission Scanning Electron Microscope (JOEL JSM-7001F). Images (b) to (e) show how the bacteria was affected by the microplasma discharge. The shape of the B. subtilis was changed and torn to pieces after the microplasma treatment. During the microplasma treatment process, every bacteria was exposed to a high electric field and UV radiation while passing through the electrodes holes generating microplasma [35]. This could cause physical damage to the bacteria and affect their shape. In particular, active radical species had an etching effect to break cell walls, and UV affects the DNA directly to sever their structure $[56,57]$. 
Citation: Shimizu K, Komuro Y, Tatematsu S, Blajan M (2011) Study of Sterilization and Disinfection in Room Air by Using Atmospheric Microplasma. Pharm Anal Acta S1:001. doi:10.4172/2153-2435.S1-001

Page 9 of 11

Figure 16 shows the photograhps of E.coli before and after Ar and air microplasma treatment for disinfection of the surface colonized bacteria. In this case, the bacteria were the nutritive cell, and their physical shape and morphology were changed after microplasma treatment as shown in Figure 16 (b) to (d). These morphology changes by plasma process were already reported by other group, but not for

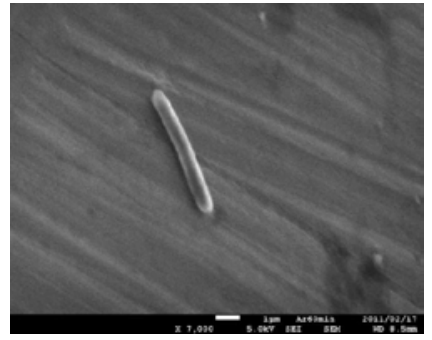

(a) before treatment $(\mathrm{x} 5000)$

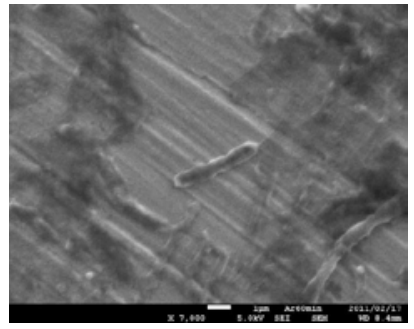

(c) after Ar microplasma treatment ( $\mathrm{Vd}=750 \mathrm{~V}, 60$ sec., $\mathrm{x} 7,000)$

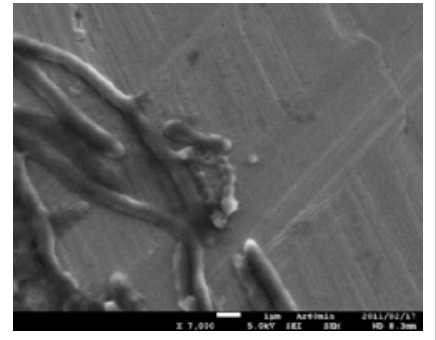

(b) after air microplasma treatment $(\mathrm{Vd}=1.4 \mathrm{kV}, 60$ sec., x 7,000)

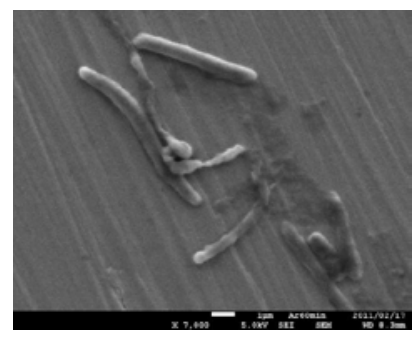

(d) after air microplasma treatment $(\mathrm{Vd}=750 \mathrm{~V}, 60$ sec., $\mathrm{x} 7,000)$

Figure 16: Photographs of E.coli before and after air and $\mathrm{Ar}$ microplasma treatment taken by SEM.

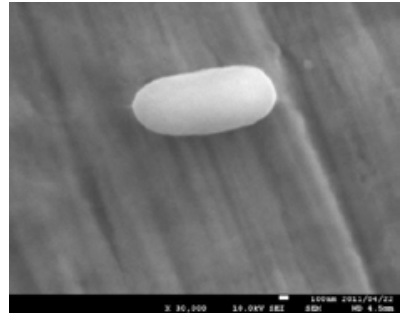

(a) before treatment ( $\mathrm{x} 30,000)$

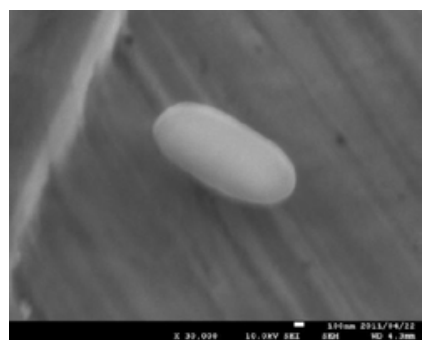

(c) after $\mathrm{O}_{2}$ microplasma treatmen $(\mathrm{Vd}=1.5 \mathrm{~V}, 60 \mathrm{sec}$., $\mathrm{x} 30,000)$

Figure 17: Photographs of Alicyclobatillus before and after $\mathrm{Ar}$ and $\mathrm{O}_{2}$ microplasma treatment taken by SEM.
Ar plasma $[58,59]$. These morphology changes could be considered by etching effect by Ar ions.

Figure 17 shows the photograhps of Alicyclobatillus acidoterrestris before and after Ar microplasma treatment. Alicyclobatillus is a Gramnegative bacteria spore. In general it is considered that various radicals derived from $\mathrm{O}_{2}$ contribute to the sterilization effects. The mechanism of various $\mathrm{O}_{2}$ radicals on the bacteria is considered to be similar to an etching process. The greater the $\mathrm{O}_{2}$ plasma exposure is, the more shrinkage of the spore is observed [59].

In contrast, there have been few studies which demonstrated that active species derived from rare gases have an etching effect. In this study, the shape of both E.coli and Alicyclobatillus were changed by using Ar microplasma treatment. One possibility is to assume that Ar ions acted directly on the bacteria. Another possibility is that $\mathrm{OH}$ radical was generated due to the dissociation of moisture on the agar medium by excited $\mathrm{Ar}$ and its $\mathrm{OH}$ radical interacted with bacteria.

\section{Conclusions and Future Work}

Indoor air control is a keen issue worldwide, since pandemics such as new influenza strains are is now serious problems in every country. Various devices which claim to generate ozone or ions to control indoor air are on the market now. But their performances are insufficient, especially for air pollutant removal [60]. Mechanisms for the sterilization or disinfection of bacteria are still not proven, and require more research to improve the performances of indoor air control devices.

In this article, a technique for indoor air control by microplasma was presented with the various data for sterilization and disinfection of the airborne bacteria or the surface colonized bacteria.

Also, various power supplies including a self-made Marx generator are presented resulting in low ozone concentration in output gas. It is also important to treat indoor air in such a way as not to generate harmful gases to human beings. Moreover, microplasma has various features as discussed in "2. About Microplasma". Discharge voltage is lower than that of other nonthermal plasma methods, or other indoor air control devices on the market. This means microplasma devices will possibly be made small, light and cost effective for commercial production. Air control devices generate ions to treat room air; in contrast, microplasma can treat room air, while room air flows into the microplasma electrode. There could be UV light emission, active species, strong electrical field between the electrodes. Odour gas molecules, bacteria or viruses could be decomposed or sterilized here.

Mechanisms of sterilization process have also been demonstrated with chemical reactions and emission spectra which could attribute emitting active species such as $\mathrm{OH}$ radicals from microplasma. But this data is still insufficient to explain these mechanisms.

In this article, there is no information about ion density generated by microplasma. Ions could be generated during the discharge process of the atmospheric microplasma which could work as air purification device. However evidence supporting claims that ions contribute to indoor air treatment processes is still not overwhelmingly conclusive. Further study is required to show sterilization and disinfection not only by the microplasma, but also the other air purification devices are "effective". As well as how safe this process is for practical use not only in home, but also hospitals, schools, and so on. 
Citation: Shimizu K, Komuro Y, Tatematsu S, Blajan M (2011) Study of Sterilization and Disinfection in Room Air by Using Atmospheric Microplasma. Pharm Anal Acta S1:001. doi:10.4172/2153-2435.S1-001

We strongly hope that the microplasma technology will be popularized to overcome both the airborne bacteria and the surface colonized bacteria in the world.

Finally, the author would like to gratefully thank Dr. Shintani of Chuo University for fruitful discussions.

\section{References}

1. Kitler ME, Gavinio P, Lavanchy D (2002) Influenza and the work of the World Health Organization. Vaccine 20: S5-S14.

2. Cowled B, Ward MP, Hamilton S, Garner G (2009) The equine influenza epidemic in Australia. Spatial and temporal descriptive analyses of a large propagating epidemic. Prev Vet Med 92: 60-70.

3. Spira AM (2003) Preparing the traveler. Lancet 361: 1368-1381.

4. Pontoriero AV, Baumeister EG, Campos AM, Savy VL, Lin YP, et al. (2003) Antigenic and genomic relation between human influenza viruses that circulated in Argentina in the period 1995_/1999 and the corresponding vaccine components. J Clin Virol 28: 130-140.

5. Yasuda H, Miura T, Kurita H, Takashima K, Mizuno A (2010) Biological Evaluation of DNA Damage in Bacteriophages Inactivated by Atmospheric Pressure Cold Plasma. Plasma Process Polym 7: 301-308.

6. Kitano K, Aoki H, Hamaguchi S (2006) Radio-Frequency-Driven AtmosphericPressure Plasmas in Contact with Liquid Water. Jpn J Appl Phys 45: 82948297.

7. Laroussi M, Sayler GS, Glascock BB, McCurdy B, Pearce ME, et al. (2004) Images of Biological Samples Undergoing Sterilization by a Glow Discharge at Atmospheric Pressure. IEEE Transactions on plasma science 27: 34-35.

8. Singh MK, Ogino A, Nagatsu M (2009) Inactivation factors of spore-forming bacteria using low-pressure microwave plasmas in an $\mathrm{N}_{2}$ and $\mathrm{O}_{2}$ gas mixture. New J Phys 11: 115027.

9. Hayashi N, Guan W, Tsutsui S, Tomari T, Hanada Y (2006) Sterilization of Medical Equipment Using Radicals Produced by Oxygen/Water vapor RF Plasma. Jpn J Appl Phys 45: 8358-8363.

10. Shintani H, Sakudo A, Burke P, McDonnell G (2010) Gas plasma sterilization of microorganisms and mechanisms of action (Review). Exp Therapeutic Med 1: 731-738.

11. Moisan M, Barbeau J, Moreau S, Pelletier J, Tabrizian M, et al. (2001) Lowtemperature sterilization using gas plasmas: a review of the experiments and an analysis of the inactivation mechanisms. Int J Pharm 226: 1-21.

12. Shimizu K, Sugiyama T, Manisha Nishamani LS (2008) Study of Air Pollution Control by Using Micro Plasma Filter. IEEE Trans. on IAS 44: 506-511.

13. Shimizu K, Sugiyama T, Kanamori M (2008) Application of microplasma for ozone generation and environmental protection. Int J Plasma Environmental Science and Technology 2: 38-43.

14. Shimizu K, Sugiyama T, Nishamani M, Kanamori M (2009) Application of Micro Plasma for NOx Removal. IEEE Trans on IAS 45: 1506-1512.

15. Shimizu K, Yamada M, Kanamori M, Blajan M (2010) Basic Study of Bacteria Inactivation at Low Discharge Voltage by Using Microplasmas. IEEE Trans on IAS 46: 641-649.

16. Shimizu K, Kanamori M, Blajan M (2010) Application of Atmospheric Microplasma for Indoor Air Treatment. Int J Plasma Environmental Science and Technology 4: 45-51.

17. Shimizu K, Blajan M, Kuwabara T (2011) Removal of Indoor Air Contaminan by Atmospheric Microplasma. IEEE Trans on IAS Digital Object Identifier: 10.1109/TIA.2011.2168509.

18. Shimizu K, Umeda A, Blajan M (2011) Surface Treatment of Polymer Film by Atmospheric Pulsed Microplasma: Study on Gas Humidity Effect for Improving the Hydrophilic Property. Jpn J Appl Phys 50: 08KA3.

19. Blajan M, Umeda A, Muramatsu S, Shimizu K (2011) Emission Spectroscopy of Pulsed Powered Microplasma for Surface Treatment of PEN Film. IEEE Trans. on IAS 47: 1100-1108.
20. Shimizu K, Muramatsu S, Sonoda T, Blajan M (2010) Water Treatment by Low Voltage Discharge in Water. Int J Plasma Environmental Science and Technology 4: 58-64

21. Shimizu K (2011) Microplasma - How it works for medical, and bio applications? -Basic and application of Atmospheric Microplasma. Proc Int Symp on Biomimetic Materials Processing BMMP-11: 7

22. Rosocha LLA, Anderson GK, Bechtold LA (1993) Treatment of Hazardous Organic Wastes Using Silent Discharge Plasmas. In: B. M. Penetrante and S. E. Schultheis, eds. Non-thermal Plasma Techniques for Pollution Control, NATO ASI Ser. 34, Part B, Oxford, Springer-Verlag Pub. : 281-308.

23. Agnihotri S, Cal MP, Prien J (2004) Destruction of 1,1,1-Trichloroethane Using Dielectric Barrier Discharge Nonthermal Plasma. J Env Engg 349-354.

24. Kogelschatz U (2002) Filamentary, Patterned, and Diffuse Barrier Discharges. IEEE Trans. Plasma Sci. 30: 1400-1408

25. Iza F, Kim GJ, Lee SM, Lee JK, Walsh JL, et al. (2008) Microplasmas: Sources, Partcicles Kinetics, and Biomedical Applications. Plasma Process Polym 5 322-344

26. Frame JW, Wheeler DJ, DeTemple TA, Eden JG (1997) Microdischarge devices fabricated in silicon. Appl Phys Lett 71: 1165-1167.

27. Abolmasov SN, Shirafuji T, Tachibana K (2005) Submillimeter Dielectric Barrier Discharges at Atmospheric Pressure: Edge Effect. IEEE Trans. on Plasma Sci 33: $941-948$.

28. Kim DB, Rhee JK, Moon SY, Choe W (2007) Feasibility study of materia surface modification by millimeter size plasmas produced in a pin to plane electrode configuration. Thin Solid Films 515: 4913-4917.

29. Schutze A, Jeong JY, Babayan SE, Park J, Selwyn GS, et al. (1998) The Atmospheric-Pressure Plasma Jet: A Review and Comparison to Other Plasma Sources. IEEE Trans. on Plasma Sci 26: 1685-1694.

30. Yin Y, Messier J, Hopwood JA (1999) Miniaturization of Inductively Coupled Plasma Sources. IEEE Trans on Plasma Sci 27: 1516-1524.

31. Iza F, Hopwood JA (2003) Low-Power Microwave Plasma Source Based on a Microstrip Split-Ring Resonator. IEEE Trans on Plasma Sci 31: 782-787.

32. Kogelschatz U (2003) Dielectric-barrier Discharges: Their History, Discharge Physics, and Industrial Applications. Plasma Chemistry and Plasma Processing 23.

33. Eliasson B, Hirth M, Kogelschatz $U$ (1987) Ozone synthesis from oxygen in dielectric barrier discharge. J Phys D Appl Phys 20: 1421-1437.

34. Kitayama J, Kuzumoto M (1997) Theoretical and experimental study on ozone generation charcteristics of an oxygen-fed ozone generator in silent discharge. J Phys D Appl Phys 30: 2453-2461.

35. Shimizu K, Ishii T, Blajan M (2010) Emission Spectroscopy of Pulsed Powe Microplasma for Atmospheric Pollution Control. IEEE Trans. on IAS 46: 11251131.

36. Yamauchi T, Suda H, Matsui Y (2007) Development of Home Appliances Using Electrostatic Atomization. J Aerosol Res 22: 5-10.

37. Stainer R, Ingraham J, Wheelis M, Painter P (1986) The Microbial World, 5th ed. New York: Prentice-Hall.

38. Beveridge T (2001) Use of the Gram stain in microbiology. Biotech Histochem 76: 111-118.

39. Kong MG, Kroesen G, Morfill G, et al. (2009) Plasma medicine: an introductory review. New Journal of Physics 11: 1-35

40. Fridman G, Friedman G, Gutsol A, Shekhter AB, Vasilets VN, et al. (2008) Applied Plasma Medicine. Plasma Process Polym 5: 503-533.

41. Stoffels E, Sakiyama Y, Graves DB (2008) Cold Atmospheric Plasma: Charged Species and Their Interactions with Cells and Tissues. IEEE Trans Plasma Sc 36: 1441-1457.

42. Goree J, Liu B, Drake D, Stoffels E (2006) Killing of S. mutans Bacteria Using a Plasma Needle at Atmospheric Pressure. IEEE Trans. On Plasma Sci 34 $1317-1324$ 
Citation: Shimizu K, Komuro Y, Tatematsu S, Blajan M (2011) Study of Sterilization and Disinfection in Room Air by Using Atmospheric Microplasma. Pharm Anal Acta S1:001. doi:10.4172/2153-2435.S1-001

Page 11 of 11

43. Laroussi M, Richardson JP, Dobbs FC (2002) Effects of nonequilibrium atmospheric pressure plasmas on the heterotrophic pathways of bacteria and on their cell morphology. App Phys Let 81: 772-774.

44. ISO14161 (2009) Sterilization of health caser products- Biological indicatorsGuidance for the selection, use and interpretation of results.

45. Machala Z, Janda M, Hensel K, et al. (2007) Emission spectroscopy of atmospheric pressure plasmas for bio-medical and environmental applications. J Mol Spectrosc 243: 194-201.

46. Kozlov KV, Wagner HE (2007) Progress in spectroscopic diagnostics of barrier discharges. Contrib Plasma Phys 47: 26-33.

47. Iordanova S, Koleva I (2007) Optical emission spectroscopy diagnostics of inductively-driven plasmas in argon gas at low pressures. Spectrochimica Acta Part B 62: 344

48. Hibert C, Gaurand I, Motret O, Pouvesle JM (1999) $[\mathrm{OH}(\mathrm{X})]$ measurements by resonant absorption spectroscopy in a pulsed dielectric barrier discharge. J Appl Phys 85: 7070-7075

49. Yoshida M, Tanaka T, Watanabe S, Takagi T, Shinohara M, et al. (2003) Experimental study on a new sterilization process using plasma source ion implantation with $\mathrm{N}_{2}$ gas. AVS 21: 1230-1236.

50. Jacobs PT, San S, Lin M, Sterilization pressure utilizing low-temperature plasmas (2001) In: Disinfection, Sterilization and Preservation. Block SS ed., New York, Lippincott Williams \& Wilkins: 747-765.

51. Liu F, Wang W, Wang S, Zheng W, Wang Y (2007) Diagnosis of OH radical by optical emission spectroscopy in a wire-plate bi-directional pulsed corona discharge. J Electrostat 65: 445-451.

52. Robertson JMC, Robertson PKJ, Lawton LA (2005) A comparison of the effectiveness of $\mathrm{TiO}_{2}$ photocatalysis and UVA photolysis for the destruction of three pathogenic micro-organisms. J Photochem Photobiol A Chem 175: 51 56.

53. Benabbou AK, Derriche Z, Felix C, Lejeune P, Guillard C (2007) Photocatalytic inactivation of Escherischia coli: Effect of concentration of $\mathrm{TiO}_{2}$ and microorganism, nature, and intensity of UV irradiation. Appl Catalysis B Environ 76: $257-263$.

54. Liang WJ, Li J, Li JX, Zhu T, Jin YQ (2010) Formaldehyde removal from gas streams by means of $\mathrm{NaNO}_{2}$ dielectric barrier discharge plasma. J Hazard Mater 175: 1090-1095

55. Atkinson R, Baulch DL, Cox RA, Crowley JN, Hampson RF, et al. (2004) Evaluated kinetic and photochemical data for atmospheric chemistry: Volume 1 - gas phase reactions of OX, HOX, NOX and SOX species. Atomos Chem Phys 4: 1461-1738.

56. Stainer R, Ingraham J, Wheelis M, Painter P (1986) The Microbial World. 5th ed. New York, Prentice-Hall.

57. Sakudo A, Shintani H (2011) Sterilizaiton and Disinfection by Plasma. New York, Nova Science Publishers, Inc.

58. Shintani H, Shimizu N, Imanishi Y, Sekiya T, Tamazawa K, et al. (2007) Inactivation of Microorganisms and Endotoxins by Low Temperature Nitrogen Gas Plasma Exposure. Biocontrol Sci 12: 131-143.

59. Rossi F, Kylian O, Hasiwa M (2006) Decontamination of Surfaces by Low Pressure Plasma Discharges. Plasma Process Polym 3: 431-442.

60. Nozaki A, Ichijo Y, Narita Y (2010) A Study on the Indoor Air Pollutant Removal Performance of Room Air Cleaners, Proc. Int Symp On Contamination Contro 2010 Tokyo: 505-510. 